\author{
Güney HACIÖMEROĞLU * 1 (D) Özlem ELMALI-ERDEM 2 (D) \\ ${ }^{1}$ Canakkale Onsekiz Mart University, Canakkale, Turkey, houney@comu.edu.tr \\ ${ }^{2}$ Canakkale Onsekiz Mart University, Canakkale, Turkey, ozlemelmali@comu.edu.tr \\ *Corresponding Author: hguney@comu.edu.tr
}

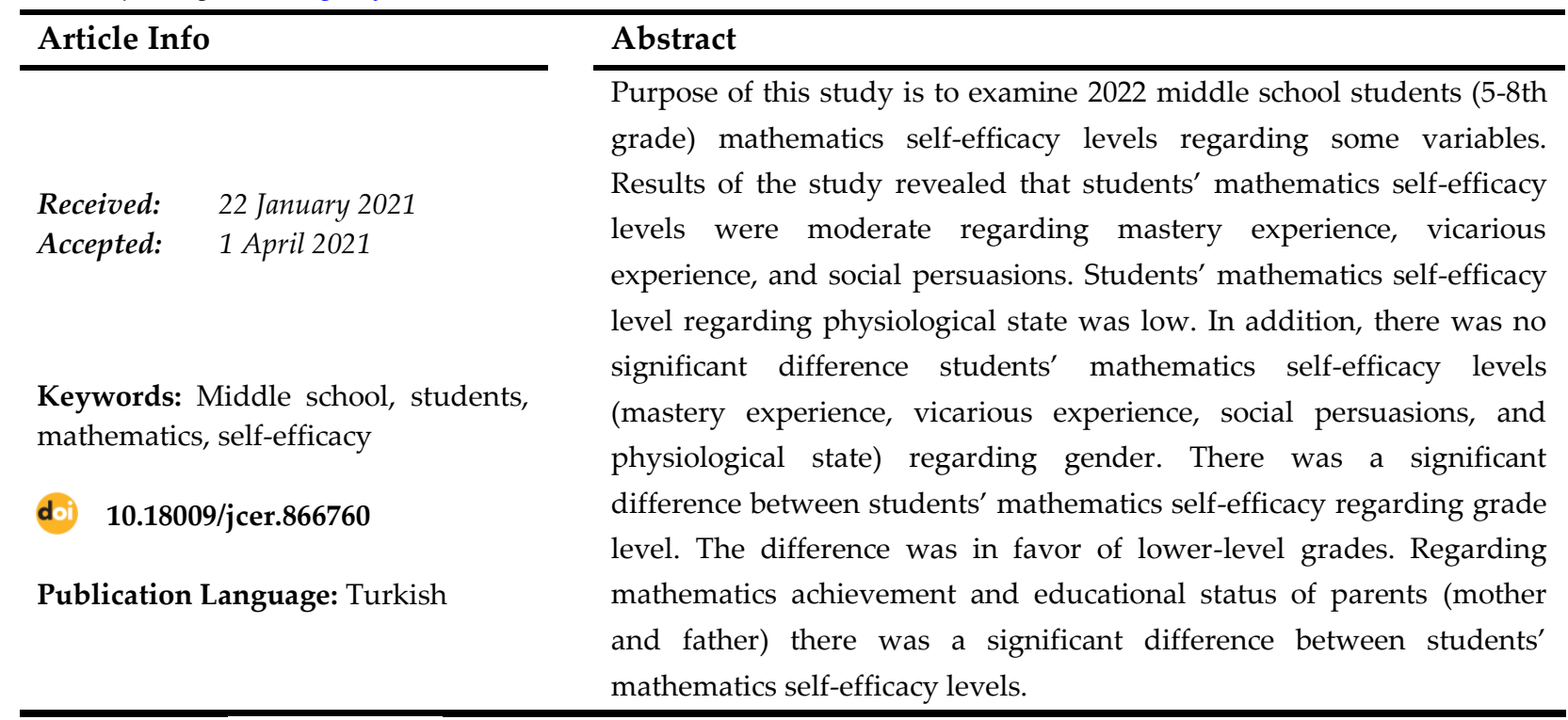

open access CrossMark CC

To cite this article: Hacıömeroğlu, G., \& Elmal1-Erdem, Ö. (2021). Ortaokul öğrencilerinin matematik öz yeterlik düzeylerinin incelenmesi. Journal of Computer and Education Research, 9 (17), 353379. DOI: $10.18009 /$ jcer. 866760

\title{
Ortaokul Öğrencilerinin Matematik Öz Yeterlik Düzeylerinin Incelenmesi
}

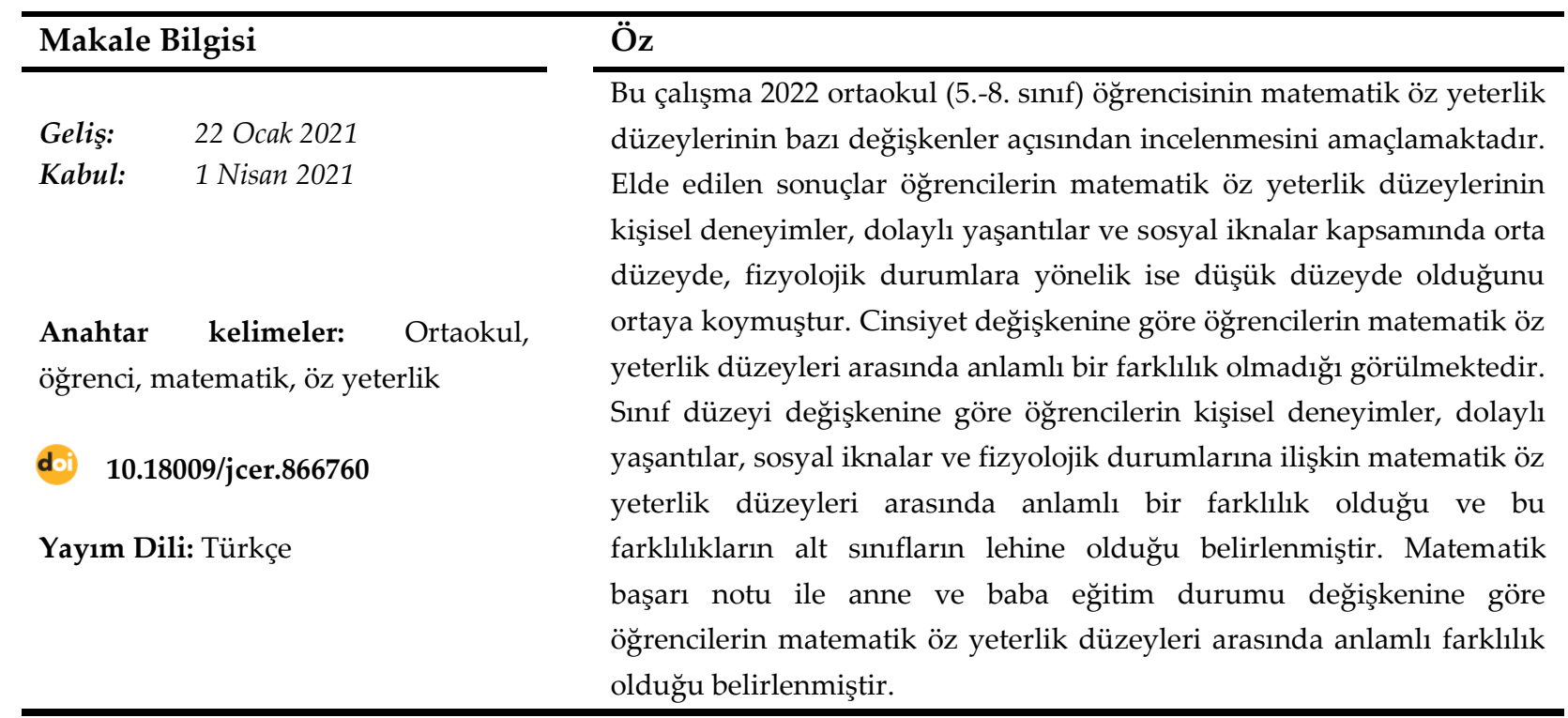




\title{
Summary
}

\section{Examining Middle School Students' Sources of Self-efficacy in Mathematics}

\author{
Güney HACIÖMEROĞLU * 1 (D) Özlem ELMALI-ERDEM ${ }^{2}$ \\ ${ }^{1}$ Canakkale Onsekiz Mart University, Canakkale, Turkey, hguney@comu.edu.tr \\ ${ }_{2}^{2}$ Canakkale Onsekiz Mart University, Canakkale, Turkey, ozlemelmali@comu.edu.tr \\ * Corresponding Author: hguney@comu.edu.tr
}

\section{Introduction}

Self-efficacy is defined as "people's judgement of their capabilities to organize and execute courses of action required to attain designated types of performances (Bandura, 1986, p. 391). In this definition, self-efficacy is related to ability for achievement of certain activity, taking exam, entering competition and speaking in public. In these difficult situations, an individual may encounter in the future. Individuals' self-efficacy levels have an important role for the students' success in mathematics. Bandura $(1986,1997)$ stated that there are four sources that affect individuals' self-efficacy. These were defined as mastery experiences, vicarious experience, social persuasions, and physiological state.

\section{Method}

In this quantitative study, survey method was utilized to examine middle school students' (5th through 8th grade) mathematics self-efficacy regarding some variables (gender, grade level, mathematics achievement, parents' education). In this study, an instrument called Sources of Middle School Mathematics Self-Efficacy Scale was utilized. This scale developed by Usher and Pajares (2009) and adapted to Turkish by Kandemir and Akbaş-Perkmen (2017). In this study, Kandemir and Akbaş-Perkmen (2017) gathered data from 5th through 8 th grade students. Therefore, we utilized the Turkish adaptation of the instrument by Kandemir and Akbaş-Perkmen (2017). The adapted instrument includes 24 items on a 5-point scale (1-strongly disagree to 5-strongly agree). The adapted instrument includes 4 sub-scales: mastery experiences, vicarious experience, social persuasions, and physiological state. Cronbach's alpha for the adapted instrument's sub-scales were calculated as $.87, .80, .87$, and .83 , respectively. In this study, convenience sampling was utilized. The data was collected from 2022 students (1013 girls and 1009 boys). The students 
were informed and then volunteered to participate in this study. Data includes $5505^{\text {th }}$ grade students, $4016^{\text {th }}$ grade students, $5057^{\text {th }}$ grade students and $5668^{\text {th }}$ grade students. Data analysis includes descriptive and inferential statistics (mean and standard deviations). Also, normality test was used to examine whether or not data has normal distribution. In order to examine students' mathematics self-efficacy regarding gender, grade level, mathematics achievement, and parents' education the following tests, Mann-Whitney U and Kruskal Wallis were applied.

\section{Results}

In this quantitative study, middle school students' mathematics self-efficacy was examined using some variables (gender, grade level, mathematics achievement, and parents' education). Results of the study revealed that middle school students' mathematics selfefficacy levels regarding mastery experiences, vicarious experience, and social persuasions were moderate. Their mathematics self-efficacy levels regarding physiological state were low. In addition, there was no significant difference students' mathematics self-efficacy levels (mastery experience, vicarious experience, social persuasions, and physiological state) regarding gender. There was a significant difference between students' mathematics selfefficacy (mastery experience, vicarious experience, social persuasions, and physiological state) regarding grade level. The difference was in favor of lower-level grades. Regarding mathematics achievement, there was a significant difference between students' mathematics self-efficacy levels. As the students' achievement increases their mathematics self-efficacy increases regarding mastery experience, vicarious experience, social persuasions, and physiological state. As the students' parents (mother and father) education level increases, students' mathematics self-efficacy regarding mastery experience, vicarious experience, social persuasions, and physiological state also develops.

\section{Discussion and Conclusion}

Results of the study showed that middle school students hold a moderate levels of mathematics self-efficacy regarding mastery experiences, vicarious experience, and social persuasions. Their self-efficacy levels regarding physiological state were low. Nevertheless, some studies found that students' mathematics self-efficacy level was high (Adal \& Yavuz, 2017; Aldan-Karademir \& Yalçın, 2019). These findings mean that the students' judgment of their capabilities to attain designated types of math performances was somehow developed. 
However, this improvement in their capabilities to do mathematics seemed to be limited. Bandura (1997) suggested that the role of the unsuccessful experiences related to mathematics affects students' self-efficacy in a negative way. Also, Eccles et al. (1984) stated that the role of the peer relationship has a significant effect on self-efficacy of the students. Social persuasion is related to encouragement from parents, teachers, and peers for students to boost their confidence in their mathematics capabilities (Senemoğlu, 2011). This study showed that encouragement from parents, teachers, and peers were not enough to boost students' confidence in their academic capabilities (Eccles et al., 1984). To what extend the effect of the encouraging words from adults, teachers and peers were effective for students should be examined as a further research (Matsui et al., 1990). The students' self-efficacy regarding physiological state was low. This means that the students' negative emotional states such as anxiety, stress, and concerns were dominant when it comes to mathematics. This situation is in the line with the results obtained from several research studies (Britner \& Pajares, 2006; Gainor \& Lent, 1998; Lent et al., 1996). As a further research study, mixed method approach should be utilized to examine students' mathematics self-efficacy levels. 


\section{Giriş}

Öz yeterlik “bireyin belli bir performansı göstermek için gerekli etkinlikleri organize edip başarılı olarak yapma kapasitesine ilişkin kendi yargısı" (Bandura, 1986, p.391) olarak tanımlanmaktadır. Senemoğlu (2011) öz yeterliği bireyin gelecekte karşılaşacağı zor durumların üstesinden gelebilmek için ne derece başarılı olacağına ilişkin kendi hakkındaki yargısı yani inancı olarak tanımlamaktadır. Ayrıca, öz yeterlik belli bir etkinliği başarma becerisi, sınava girme, yarışmaya katılma, bir topluluk önünde konuşma gibi bireyin gelecekte karşılaşabileceği zor durumlarda karşımıza çıkmaktadır. Matematik dersi söz konusu olduğunda bireylerin bu derste başarı olmalarında öz yeterlik düzeylerinin önemli bir yere sahip olduğu söylenebilir. Bandura (1986, 1997), öğrencilerin öz yeterlik inançlarının kişisel deneyimler, dolaylı yaşantılar, sosyal ikna ve psikolojik durumlar olmak üzere dört kaynaktan elde ettikleri bilgileri yorumlamaları sonucu oluştuğunu ve geliştiğini vurgulamaktadır.

\section{Kişisel Deneyimler}

Kişisel deneyimler kapsamında birey bir akademik görevi (etkinlik, çalışma, ödev) tamamladığında elde edilen sonuçları inceler ve değerlendirir. Birey gösterdiği çabanın onu başarıya götürdügüne inandığında buna benzer performansları yerine getirmek için kendine olan güveni artmaktadır. Ancak, bireyin göstermiş olduğu çaba sonucunda istenilen sonuçlar elde edilmediğinde benzer bir durumda yapabileceğine dair kendine olan güveni kaybolmaktadır (Usher \& Pajares, 2008b). Buna örnek olarak, bir akademik yıl boyunca matematik derslerinde yüksek not olan öğrencilerin gelecekte bu alanda yetenekli olduklarına inanma eğilimi gösterdiklerinin altını çizmektedir (Usher \& Pajares, 2008b). Buna bağlı olarak, öğrencilerin gelecekte başarılarının devam etme eğiliminde olacağı vurgulanmaktadır. Kişisel deneyimler, bireyin başarılı veya başarısız olduğu çalışmalar sonucunda elde ettiği bilgiler olarak tanımlanmaktadır (Senemoğlu, 2011). Bir başka deyişle, öğrenciler karşılaştı̆̆ı görevlerde (etkinlikler, problem çözme, ödev) zaman zaman başarısızlık gösterdiğinde bile matematiksel becerilerinde yavaş da olsa bir gelişim gösterdiklerini fark edebilmektedir. Ancak, bireyin göstermiş olduğu bütün çabaya rağmen başarısızlıkla sonuçlanan deneyimler öğrencilerin öz yeterlik inançlarını olumsuz yönde etkilemektedir (Usher \& Pajares, 2008b). Kişisel deneyimler en çok birey zor bir durumla karşılaşıp bunun üstesinden başarıyla geldiğinde etkisini ortaya koymaktadır (Bandura, 
1997). Örneğin, birçok öğrencinin çözmekte zorlandığı bir matematik problemini çözen bir bireyin edindiği bu olumlu deneyimle beraber matematiksel becerilerini yerinde ve etkili kullanması öz yeterliklerini yükseltmektedir. Kişisel deneyimler öz yeterlik inançlarının oluşumunda, gelişiminde en etkili kaynak olarak gösterilmektedir. Araştırmalar kişisel deneyimlerin öz yeterlik inancının en önemli yordayıcısı olduğunu vurgulamaktadır (Britner \& Pajares, 2006; Hampton, 1998; Klassen, 2004; Lopez vd., 1997; Pajares vd., 2007). Kişisel deneyimleri inceleyen birçok çalışma öğrencilerden belirli bir derse yönelik olarak geçmiş ve şimdiki performanslarını derecelendirmelerini istemiştir (Britner \& Pajares, 2006). Bazı araştırmalarda öğrencilerden başarı notunu belirtmesi istenerek (Klassen, 2004; Matsui vd., 1990), uygulanan test sonuçları ile katıldıkları okul dışı ekstra etkinlikler (Chin \& Kameoka, 2002) kullanılarak kişisel deneyimler ölçülmüştür. Johnson (2005) öğrencilerden geçmiş deneyimlerini ‘hiç deneyimim yok' ile 'çok deneyimim var' aralığında derecelendirmelerini istemiştir. Bu çalışmalarda kişisel deneyimlere yönelik toplanan bu verilerin Bandura'nın (1997) tanımıyla tam olarak örtüşmediği görülmektedir. Matematik performanslarına yönelik toplanan bu veriler bireyin bu sonuçları nasıl algıladığına bağlı olarak değişkenlik göstermektedir. Örneğin, matematik derslerinde zorlanan bir öğrenci için bir matematik ödevinden 5 üzerinden 3 alması bir başarıdır. Ancak, genellikle matematik derslerinde 5 alan başka bir öğrenci için 5 üzerinden 3 almak çok üzücü olabilir. Bir başka deyişle, aynı kişisel performanslara ilişkin edinilen deneyimleri bireyin nasıl yorumladığı algılanan öz yeterliğini etkilemeyebilir veya azaltabilir (Bandura, 1997). Bu duruma paralel olarak, araştırmalar algılanan kişisel deneyimlerin ölçülen kişisel deneyimlere (ölçülen test sonuçları, katıldıkları okul dışı ekstra etkinlikler vb.) kıyasla algılanan öz yeterliğin daha iyi bir yordayıcısı olduğunu belirlemiştir (Lane, 2002; Lopez vd., 1997).

\section{Dolaylı Yaşantılar}

Öğrenciler yeterlik inançlarını dolaylı yaşantılar yoluyla başkalarını (sınıf arkadaşlarını, aile üyelerini, televizyonun rolünü ve diğer medya araçlarını) gözlemleyerek inşa eder (Bandura, 2004). Bunu birey kendi deneyimlerine paralel diğer kişilerin başarılı veya başarısız çalışmalarını gözlemleyerek gerçekleştirir. Örneğin, bir matematik sınavında 20 puan üzerinden 8 alan bir öğrenci bu sonucu sınıftaki diğer arkadaşlarının aldıkları puana göre değerlendirir. Eğer diğer öğrenciler kendisinden daha düşük puan aldı ise bireyin öz yeterlik inancı artacaktır. Ancak, sınıf arkadaşları kendisinden daha yüksek puan aldı ise bu 
durumda kendisinin öz güveni sarsılır (Usher \& Pajares, 2008a). Bir başka deyişle, birey bir performansı yerine getirme hususunda elde ettiği sonuçları değerlendirirken kendi deneyimlerine benzer diğer kişilerin başarılı ya da başarısız oldukları durumlara bağlı olarak değerlendirme yapar. Öğrenciler kendi becerilerinden veya kısıtlı deneyimlerinden emin olamadıkları durumlarda sosyal modellerin öz yeterliklerin gelişimi üstünde önemli bir rolü olduğu belirtilmektedir. Öğrenciler akademik başarılarını değerlendirirken kendilerini başkalarıyla (sınıf arkadaşları ve yetişkinler) kıyaslar. Gözlemlenen kişilerin göstermiş oldukları başarı ve/veya başarısızlıkların bireylerin kendilerine olan güvenleri üzerinde etkili olduğu vurgulanmaktadır (Usher \& Pajares, 2008b). Eccles ve diğerleri (1984) özellikle ilkokuldan ortaokula geçiş dönemlerinde gözlemlenen modellerin genç öğrenciler üzerindeki etkisinin daha fazla olduğunun altını çizmektedir. Örneğin, sınıf arkadaşının zor bir matematik problemini çözmede başarılı olduğunu gördüğünde, bu problemi yapabileceğine dair kendine olan güveni artmaktadır. Buna ek olarak, benzer özelliklere (yaş, cinsiyet, sınıf düzeyi) sahip öğrencilerin gözlemlenen modeller olarak etkisinin daha fazla olduğu belirtilmektedir. Dolaylı yaşantıları inceleyen araştırmalarda öğrencilerden ilgi duydukları akademik alanda yetkinlik gösteren modellere (akran, yetişkin, sınıftaki yakın arkadaş, ebeveynler, öğretmenler, kendinden büyük öğrenciler vb.) ne düzeyde maruz kaldıklarını derecelendirmeleri istenmiştir. Araştırmaların dolaylı yaşantıları akran ve yetişkin modelleriyle (Lent vd., 1996), akranla ilişkili maddeler aracılığıyla (Klassen, 2004), yetişkin modelleriyle (Hampton, 1998) olan deneyimlerden yola çıkarak incelediği görülmektedir.

\section{Sosyal İkna}

Öğrencilerin güvendikleri kişilerin (ebeveynlerin, öğretmenlerin ve akranların) cesaretlendirmesi akademik yeteneklerine ilişkin olarak kendilerine olan güvenlerini artırmaktadır. Senemoğlu (2011) teşvik, nasihat, öğüt anlamında ifade edilen sözlerin bireyin öz yeterliğini etkilediğini vurgulamaktadır. Ancak, Schunk (1984) sosyal iknanın etkili olabilmesi için öğrencilere verilecek dönütlerin onların öz yeterliklerini destekleyecek şekilde sunulması gerektiğini belirtmektedir. Bu sebeple, sosyal iknayı inceleyen araştırmalar öğrencilerden akademik becerileri/yetenekleri hakkında önem verdikleri kişilerin (akranlar, ebeveynler, öğretmenler ve diğer yetişkinler vb.) ifade ettiği cesaretlendirici mesajları derecelendirmelerini istemiştir (Matsui vd., 1990). 


\section{Psikolojik Durumlar}

Kayg1, stres, bitkinlik gibi duygusal ve psikolojik durumlar öz yeterlik inancı hakkında bilgi verici niteliktedir. Öğrencilerin gerçekleştirmekle yükümlü olduğu performanslara yönelik gösterdiği güçlü duygusal tepkiler başarı veya başarısızlık hakkında ipuçları niteliğindedir. Belirli bir derse ilişkin korku ve endişe yaşayan öğrenciler muhtemelen bu alana yönelik beceri eksikliklerine sahiptir (Usher \& Pajares, 2008b). Örneğin, matematik derslerinde başarı göstermede zorlanan öğrencilerin bu derste kaygı ve endişe duygularının yüksek olduğu görülmektedir. Aynı zamanda, bu öğrencilerin matematik dersine ilişkin görevleri yerine getirmede eksikliklerinin olduğu dikkat çekmektedir. Bandura (1997) bireylerin ideal şartlarda yani ne çok yüksek ne de çok düşük psikolojik uyarıcılar altında kendisinden beklenilen görevleri yerine getirdiklerini belirtmiştir. Bir başka deyişle, öğrencilerin fiziksel ve duygusal iyi oluşunu geliştirirken olumsuz duygusal durumlar azaltıldığında öz yeterlik güçlenmektedir. Psikolojik durumların öğrencilerin matematik dersine yönelik kaygılarını ölçerek ve kaygıyla ilgili maddeler kullanılarak incelendiği görülmektedir (Britner \& Pajares, 2006; Gainor \& Lent, 1998; Lent vd., 1996). Bazı çalışmalarda ise bu durum öğrencilerin matematik dersinden ne düzeyde hoşlandığını (Matsui vd., 1990), matematik dersini düşündügünnde kendini hasta veya depresyonda hissedip hissetmediğini (Klassen, 2004) veya psikolojik olarak okulun kendisini nasıl ve ne düzeyde etkilediğini derecelendirmeleri istenerek incelendiği görülmektedir. Ancak, ruh hali, fiziksel dayanıklılık, sıkıntı veya sevinç düzeyi olmak üzere birçok faktörün psikolojik durumları etkileyebileceği ve artan psikolojik uyarılmanın azalan öz yeterlikle sonuçlanmayabileceği dikkate alınmalıdır (Usher \& Pajares, 2008a). Bu duruma örnek olarak, Bandura (1997) iyi bir ruh halinde başarılı olan bireyin yeterlik inancının artacağını vurgular. Benzer şekilde, birey duygusal uyarılmalarını (kaygı, endişe, stress vb.) bir engel olarak görmeden aksine kabullenip üstesinden gelmek için çaba gösterdiğinde öz yeterlikleri artar.

Bazı araştırmaların cinsiyet, sınıf ve başarı düzeyi, anne ve baba eğitim durumu gibi değişkenlere göre bireylerin matematik öz yeterliklerini incelediği görülmektedir. Cinsiyet değişkenine göre ilkokul düzeyinde kız ve erkek öğrencilerin matematik dersine yönelik yeterlik inançlarının birbirine benzer olduğu görülürken bu durumun ortaokul ve lise düzeyinde değişim gösterdiği belirlenmiştir (Pajares, 2005). Meece (1991) kız öğrencilerin 
yeterlik inançlarının erkek öğrencilerden düşük olduğunu belirlemiştir. Lloyd ve diğerleri (2005) ise kızların matematik başarısının erkeklerle aynı ve hatta daha yüksek olmasına rağmen kendilerine olan güvenlerinin erkek öğrencilerden düşük olduğunu belirlemiştir. Benzer şekilde, Louis ve Mistele (2011) erkek öğrencilerin matematik öz yeterliklerinin kızlardan yüksek olduğunu belirlemiştir. Gao (2020) kız öğrencilerin matematik öz yeterlik söz konusu olduğunda sosyal iknaya bağlı daha fazla destek aldıklarını ancak kaygı düzeylerinin erkek öğrencilere göre daha yüksek olduğunu belirlemiştir. Bazı araştırmalar cinsiyet değişkenine göre kız ve erkek öğrencilerin öz yeterlik düzeyleri arasında anlamlı bir farklılık olmadığını ortaya koymuştur (Britner \& Pajares, 2006; İsiksal \& Askar, 2005; Lent vd., 1996; Pajares \& Graham, 1999; Pajares vd., 2007). Bununla beraber, bazı araştırmalar ise erkeklerin kızlara göre matematik öz yeterlik düzeylerinin yüksek olduğunu ortaya koymuştur (Hackett \& Betz, 1989). Lopez ve diğerleri (1997) tarafından yapılan çalışma sonuçları matematik dersi söz konusu olduğunda kızların erkeklere kıyasla daha güçlü sosyal ikna ve dolaylı yaşantılara sahip olduğunu ortaya koymuştur. Ulusal düzeyde yapılan araştırmalar incelendiğinde uluslararası düzeyde yapılan yayınlara kıyasla çalışmaların oldukça az sayıda olduğu dikkate çekmektedir. Ulusal düzeyde, Adal ve Yavuz (2017) tarafından yapılan çalışmalar cinsiyet değişkenine göre kız ve erkek öğrencilerin matematik öz yeterlikleri arasında erkek öğrenciler lehine anlamlı bir farklılık olduğunu belirtmiştir. Benzer şekilde Aldan Karademir ve Yalçın (2019) çalışmasında cinsiyet değişkenine göre kız ve erkek öğrencilerin matematik öz yeterlikleri arasında anlamlı bir farklılık olduğu tespit edilmiştir. Bu farklılığın kişisel deneyimlere yönelik olarak erkek öğrencilerin lehine olduğu belirtilmiştir. Arslan (2017), Koç ve Arslan (2017) ile Medikoğlu (2020) kız öğrencilerin yeterlik inançlarının erkek öğrencilerden daha yüksek olduğu sonucuna ulaşmıştır. Bununla beraber bazı araştırmalar (Akay \& Boz, 2011; Sevgi \& Yakışıklı, 2020; Sevgi \& Zihar, 2020) ise cinsiyet değişkenine göre kız ve erkek öğrenciler arasında anlamlı bir farklılık olmadığını tespit etmiştir. Bunun aksine Çakıroğlu ve Işıksal (2009) erkek öğrencilerin matematik öz yeterliklerinin kız öğrencilerden yüksek olduğunu belirlemiştir. Bandura (1997) ilkokuldan ortaokula, ortaokuldan liseye geçiş dönemlerinde öğrencilerin yeterlik inançlarının ve gelişimlerinin incelenmesi gerektiğini vurgulamaktadır. Buna paralel olarak, Usher ve Pajares (2008b) bu geçiş dönemlerinde dolaylı yaşantılar veya sosyal iknanın incelenmesinin öğrencilerin yeterlik inançları hakkında bilgi edinmemize yardımcı olacağını belirtmektedir. Araştırmalar incelendiğinde (Adal \& Yavuz, 2017; Sevgi \& Zihar, 2020) sınıf düzeyi 
değişkenine göre bakıldığında öğrencilerin matematik öz yeterlikleri arasında anlamlı bir farklılık olduğunu ortaya koymuştur. Sınıf düzeyi yükseldikçe öğrencilerin matematik öz yeterlik algılarının düştüğü belirlenmiştir. Bunun aksine Çakıroğlu ve Işıksal (2009) ise sınıf düzeyi yükseldikçe öğrencilerin matematik öz yeterlik algılarının yükseldiğini tespit etmiştir. Sevgi ve Yakışıklı (2020) ise sınıf düzeyi değişkenine göre bakıldığında öğrencilerin matematik öz yeterlikleri arasında anlamlı bir farklılık olmadığı sonucuna ulaşmıştır. İsiksal ve Askar (2005) başarı düzeyi değişkenine göre öğrencilerin öz yeterlik düzeyleri arasında anlamlı farklılık olduğunu belirlemiştir. Sevgi ve Yakışıklı (2020) öz yeterlik ile başarı notu arasında anlamlı bir farklılık olmadığını vurgulamıştır. Bazı araştırmalar ise öz yeterlik ile matematik başarısı arasında pozitif ve anlamlı bir ilişki olduğunu ortaya koymuştur (Cooper \& Robinson, 1991; Hackett \& Betz, 1989; Kahramanoğlu \& Deniz, 2017). Matematik başarı düzeyi değişkenine göre öğrencilerin matematik öz yeterlikleri arasında anlamlı bir farklılık olduğu ve bu farklılı̆̆ın başarı notu yüksek olan öğrenciler lehine olduğu belirlenmiştir (Sevgi \& Zihar, 2020).

Bandura (1986, 1997) öz yeterlik inancının akademik performansların yordayıcısı olduğunu vurgulamaktadır. Pajares ve Graham (1999) tarafından yapılan araştırma sonucu matematik öz yeterlik inançlarının öğrencilerin matematik performanslarının yordayıcısı olduğunu desteklemektedir. Araştırmalar kişisel deneyimler, dolaylı yaşantılar, sosyal ikna ve psikolojik durumlar arasındaki korelasyonları incelediğinde bu dört kaynak arasında anlamlı bir ilişki olduğunu belirlemiştir (Britner \& Pajares, 2006; Lent vd., 1996; Pajares vd., 2007). Ancak bazı araştırmalar ise kişisel deneyimler ile dolaylı yaşantılar (Matsui vd., 1990), psikolojik durumlar ile dolaylı yaşantılar (Hampton \& Mason, 2003), psikolojik durumlar ile sosyal ikna (Hampton \& Mason, 2003) arasındaki korelasyonlara bakıldığında anlamlı bir ilişki olmadığını belirlemiştir. Butz ve Usher (2015) ilkokul ve ortaokul öğrencilerinin kişisel deneyimler ile sosyal iknanın matematik öz yeterlikleri üzerinde etkili birer faktör olduğunu belirlemiştir. Buna ek olarak, başarılı performansların öğrencilerin öz yeterlikleri üzerinde önemli bir etkisi olduğunu ortaya koymuştur. Buna paralel olarak, Kahramanoğlu ve Deniz (2017) matematik öz yeterlik ile matematik başarısı arasında pozitif ve anlamlı bir ilişki olduğunu ortaya koymuştur. Kişisel deneyimlerin tek başına matematik başarısının anlamlı bir yordayıcısı olduğunu belirlemiştir. Öztürk ve diğerleri (2020) tarafından yapılan çalışma matematik öz yeterliğin problem çözme becerilerinin önemli bir yordayıcısı olduğunu ortaya koymuştur. Arens ve diğerleri (2020) matematik öz yeterlik ile matematik başarısı arasında 
tek yönlü bir ilişki olduğunu belirlemiştir. Bazı araştırmalar (Li vd., 2021) öğrencilerin öz yeterlik ve matematik başarısı arasındaki ilişkiyi incelemiştir. Elde edilen sonuçlar, öğrencilerin matematik öz yeterliklerinin matematik performanslarının güçlü ve önemli bir yordayıcısı olduğunu ortaya koymuştur.

Ulusal düzeyde yapılan araştırmalar incelendiğinde öz yeterlik konusunda çoğunlukla öğretmen adayları (Gün vd., 2021), öğretmenler (Pul \& Aksu, 2020) ve okul yöneticilerinin (Ulukaya vd., 2017) öz yeterlik düzeylerini incelemek amacıyla yapıldığ görülmektedir. Bu çalışmalara kıyasla öğrencilerin öz yeterlik düzeylerini inceleyen çalışmaların sayısında son yıllarda artış olmasına rağmen daha fazla çalışmaya ihtiyaç olduğu görülmektedir (Arslan, 2018, 2019; Medikoğlu, 2020). Bu durum öğrencilerin matematik öz yeterlik düzeylerini incelemeye yönelik daha fazla çalışmanın yapılması ihtiyacını ortaya koymuştur.

\section{Amaç}

$\mathrm{Bu}$ araştırma ortaokul (5-8. sınıf) öğrencilerinin matematik öz yeterlik düzeylerinin cinsiyet, sınıf düzeyi, matematik başarı notu değişkenleri açısından incelenmesini amaçlamaktadır. Bu amaç doğrultusunda aşağıdaki araştırma sorularına cevap aranmıştır:

1. Ortaokul (5.-8. sınıf) öğrencilerinin kişisel deneyimler, dolaylı yaşantılar, sosyal iknalar ve fizyolojik durumlar kapsamında matematik öz yeterlikleri ne düzeydedir?

2. Cinsiyet değişkenine göre ortaokul (5-8. sınıf) öğrencilerinin kişisel deneyimler, dolaylı yaşantılar, sosyal iknalar ve fizyolojik durumlar kapsamında matematik öz yeterlik ortalama puanları arasında anlamlı bir farklılık var mıdır?

3. Sınıf düzeyi değiş̧kenine göre ortaokul (5-8. sınıf) öğrencilerinin kişisel deneyimler, dolaylı yaşantılar, sosyal iknalar ve fizyolojik durumlar kapsamında matematik öz yeterlik ortalama puanları arasında anlamlı bir farklılık var mıdır?

4. Matematik başarı notu değişkenine göre ortaokul (5-8. sınıf) öğrencilerinin kişisel deneyimler, dolaylı yaşantılar, sosyal iknalar ve fizyolojik durumlar kapsamında matematik öz yeterlik ortalama puanları arasında anlamlı bir farklılık var mıdır?

5. Anne eğitim durumu değişkenine göre ortaokul (5-8. sınıf) öğrencilerinin kişisel deneyimler, dolaylı yaşantılar, sosyal iknalar ve fizyolojik durumlar kapsaminda matematik öz yeterlik ortalama puanları arasında anlamlı bir farklılık var mıdır? 
6. Baba eğitim durumu değişkenine göre ortaokul (5-8. sınıf) öğrencilerinin kişisel deneyimler, dolaylı yaşantılar, sosyal iknalar ve fizyolojik durumlar kapsamında matematik öz yeterlik ortalama puanları arasında anlamlı bir farklılık var mıdır?

7. Ortaokul (5-8. sınıf) öğrencilerinin matematik öz yeterlik kaynakları (kişisel deneyimler, dolaylı yaşantılar, sosyal ikna ve psikolojik durumlar) arasındaki ilişki ne düzeydedir?

\section{Yöntem}

$\mathrm{Bu}$ çalışmada nicel araştırma yöntemlerinden tarama modeli kullanılmıştır. Tarama modeli genel bir yargıya ulaşmak için var olan durumu evrenden alınacak örneklem üzerinden yapılacak düzenlemelerle resmetme olarak ifade edilmektedir (Karasar, 2003). Bu sebeple, bu araştırma kapsamında ortaokul (5-8. sınıf) öğrencilerinin matematik öz yeterlik düzeylerinin incelenmesi amaçlandığından tarama modeli kullanılmıştır.

\section{Örneklem}

$\mathrm{Bu}$ araştırmanın evrenini Marmara bölgesinde yer alan bir ilin ortaokul düzeyinde öğrenim gören öğrenciler oluşturmaktadır. Örneklemini ise bu il merkezi ortaokullarında öğrenim gören öğrenciler oluşturmaktadır. Bu sebeple, bu çalışmada uygun örnekleme tercih edilmiş, veriler Milli Eğitim Bakanlığına bağlı 6 devlet ortaokulundan toplanmıştır. Uygun örnekleme bir başka adıyla kazara örnekleme olarak adlandırılmaktadır. Bu yaklaşım kolay ulaşılabilir ve uygulama yapılabilen birimlerden ihtiyaç duyulan örnekleme ulaşılıncaya kadar verilerin toplanmasını içermektedir (Cohen vd., 2018).

\section{Çalışma Grubu}

Araştırmanın çalışma grubunu 1013 kız ve 1009 erkek olmak üzere toplam 2022 öğrenci oluşturmaktadır. Bu çalışmaya 5. sınıfta öğrenim gören 550 öğrenci, 6. sınıfta öğrenim gören 401 öğrenci, 7. Sinıfta öğrenim gören 505 ve 8. sinıfta öğrenim gören 566 öğrenci katılmıştır.

\section{Veri Toplama Aracı}

Matematik Öz Yeterlik Kaynakları Ölçeği

Öz Yeterlik Kaynakları Ölçeği, ortaokul öğrencilerinin matematik öz yeterlik kaynaklarını ölçme amacı ile Usher ve Pajares (2009) tarafından geliştirilmiştir. Özgün ölçek 6'lı Likert tipinde olup 24 maddeden oluşmaktadır. Kandemir ve Akbaş-Perkmen (2017) 
tarafından yapılan uyarlama çalışmasında veriler ortaokul (5-8. sınıf) öğrencilerinden toplanan veriler üzerinden gerçekleştirilmiştir. Bu araştırma bütün ortaokul düzeylerini içine alarak yapılmış bir uyarlama çalışması olması sebebiyle Kandemir ve Akbaş-Perkmen (2017) ölçeği kullanılmıştır. Uyarlanan ölçekte yer alan her bir maddeye ilişkin öğrencilerin görüşlerinin belirlenmesinde hiç katılmıyorum (1) ile tamamen katılıyorum (5) aralıkları 5'li Likert tipinde sunularak kullanılmıştır. Bu versiyon, özgün haliyle aynı kişisel deneyimler, dolaylı yaşantılar, sosyal iknalar ve fizyolojik durumlar olmak üzere dört faktörlü bir yapı oluşturmuştur. Alt faktörler için Cronbach alfa güvenilirlik katsayısı sırasıyla .87, .80, .87 ve .83 olarak hesaplanmıştır.

İşlem

Bu araştırma kapsamında 2019-2020 Eğitim öğretim yılının Güz döneminde İl Milli Eğitim Müdürlüğünden ve çalışmanın yapıldığı il merkezindeki üniversitenin etik kurulundan alınan izinlerle beraber okul ziyaretleri yapılarak okul idaresine, öğretmenlere ve öğrencilere yapılmak istenilen çalışma hakkında bilgi verilmiştir. Daha sonra ise gönüllülük esasına göre veriler okul idaresinin belirlediği eğitim-öğretimi aksatmayacak bir zaman diliminde uygulanarak toplanmıştır. Bu araştırma kapsamında veriler 2019-2020 eğitim öğretim yılında Marmara bölgesinde yer alan bir il merkezinin Milli Eğitim Müdürlüğüne bağlı 6 devlet ortaokulundan toplanmıştır. Okullardan randevu alınarak belirlenen uygun zaman dilimlerinde veri toplama işlemi araştırmacılar tarafından gerçekleştirilmiştir.

\section{Veri Analizi}

$\mathrm{Bu}$ araştırmada öncelikle veriler SPSS 22.0 programı kullanılarak analiz edilmiştir. Ölçekte yer alan maddeler değerlendirilirken “ölçme sonuçları dizisindeki en büyük değer ile en küçük değer arasındaki farkın belirlenen grup sayısına bölünmesiyle (Kan, 2009, s. 407)" ortaya çıkan grup aralık katsayısı değeri kullanılmıştır. Bu değer kullanılarak ortaokul öğrencilerinin Matematik Öz Yeterlik Kaynakları Ölçeğine vermiş oldukları cevaplar değerlendirilmiştir. Ölçek kullanılarak toplanan veriler değerlendirilirken 4.50-5.00 tamamen katılıyorum, 3.50-4.49 katılıyorum, 2.50-3.49 kararsızım, 1.50-2.49 katılmıyorum, 1.00-1.49 hiç katılmıyorum aralıkları kullanılmıştır. Ortaokul öğrencilerinin matematik öz yeterlik düzeylerini incelemek amacıyla betimsel istatistikler kapsamında aritmetik ortalama ve standart sapma değerleri hesaplanmıştır. Matematik başarı notu olarak veriler toplanırken 
öğrencilerin dönem sonu karne notunu belirtmeleri istenmiştir. Bu çalışmada toplanan veriler normal dağılım gösterip göstermediğini belirlemek amacıyla normallik testi yapılmıştır. Cinsiyet, sınıf düzeyi, matematik başarısı, anne-baba eğitim durumu değişkenlerine göre öğrencilerin matematik öz yeterlik düzeyleri arasında anlamlı bir farklılık olup olmadığını incelemek amaciyla Mann-Whitney U ve Kruskal Wallis testleri yapılmıştır. Matematik öz yeterlik kaynakları (kişisel deneyimler, dolaylı yaşantılar, sosyal ikna ve psikolojik durumlar) arasındaki ilişkinin derecesinin incelemek amacıyla Spearman sıra korelasyon analizi yapılmıştır. Bu çalışmada toplanan veriler normal dağılım göstermediği için parametrik olmayan testler uygulanmıştır.

\section{Bulgular}

$\mathrm{Bu}$ araştırmada ortaokul (5.-8.sınıf) öğrencilerinin matematik öz yeterlik düzeylerini bazı değişkenler (cinsiyet, sınıf düzeyi, matematik başarı notu) açısından incelemek amaçlanmıştır. $\mathrm{Bu}$ amaç doğrultusunda ilk olarak toplanan verilerin normallik varsayımını sağlayıp sağlamadığını belirlemek amacıyla normallik testi yapılmıştır.

Tablo 1. Öz yeterlik kaynakları ölçeğine ilişkin puanların normallik testi sonuçları

\begin{tabular}{llcc}
\hline & \multicolumn{3}{l}{ Kolmogorov-Smirnov } \\
\hline & İstatistik & $\mathrm{df}$ & $\mathrm{p}$ \\
Kişisel Deneyimler & .060 & 2022 & .000 \\
Dolaylı Yaşantılar & .069 & 2022 & .000 \\
Sosyal İknalar & .060 & 2022 & .000 \\
Fizyolojik Durumlar & .126 & 2022 & .000 \\
\hline
\end{tabular}

Elde edilen bulgular, p değerlerinin 0.000 olması ve $\mathrm{p}<.05$ olması sebebiyle verilerin varyanslarının homojen olmadığı belirlenmiştir. Ortaokul (5-8. sınıf) öğrencilerinin Matematik Öz yeterlik Kaynakları Ölçeğinde alan maddelere ilişkin vermiş oldukları cevapların betimsel istatistikleri Tablo 1'de sunulmuştur.

Tablo 2. Ortaokul (5-8. Sınıf) öğrencilerinin matematik öz yeterlik kaynakları ölçeği alt boyutlarına ilişkin betimsel istatistikler

\begin{tabular}{llll}
\hline Ölçekte yer alan alt boyutlar & $\mathrm{N}$ & $\overline{\mathrm{X}}$ & ss \\
\hline Kişisel Deneyimler & 2022 & 3.20 & 0.81 \\
Dolaylı Yaşantılar & 2022 & 3.43 & 0.88 \\
Sosyal İknalar & 2022 & 3.23 & 1.15 \\
Fizyolojik Durumlar & 2022 & 2.36 & 1.19 \\
\hline
\end{tabular}

Ortaokul öğrencilerinin kişisel deneyimler, dolaylı yaşantılar ve sosyal iknalar alt boyutlarına ilişkin ortalama puanlarının "kararsızım” aralığına karşılık geldiği belirlenmiştir. Fizyolojik durumlara ilişkin ortalama puanlarının "katılmıyorum" aralığında 
olduğu tespit edilmiştir. Bu durum ortaokul öğrencilerinin matematik dersi söz konusu olduğunda öz yeterliklerinin kısmen olumlu olmasına rağmen düşük seviyede olduğunu ortaya koymuştur.

Tablo 3. Cinsiyet değişkenine göre ortaokul (5.-8. Sinıf) öğrencilerinin matematik öz yeterlik kaynakları ölçeği alt boyutlarına ilişkin Mann-Whitney U testi sonuçları

\begin{tabular}{lllllll}
\hline Ölçek Alt Boyutları & Cinsiyet & $\mathrm{N}$ & $\begin{array}{l}\text { Siralar } \\
\text { Ortalaması }\end{array}$ & $\begin{array}{l}\text { Sira } \\
\text { Toplamı }\end{array}$ & U & p \\
& Kiz & 1013 & 993.57 & 1006485.50 & 492894.5 & 0.161 \\
& Erkşisel Deneyimler & 1009 & 1029.50 & 1038767.50 & & \\
& Kiz & 1013 & 1020.59 & 1033856.50 & 501851.5 & 0.482 \\
Dolaylı Yaşantılar & Erkek & 1009 & 1002.38 & 1011396.50 & & \\
& Kız & 1013 & 995.41 & 1008353.50 & 494762.5 & 0.214 \\
Sosyal İknalar & Erkek & 1009 & 1027.65 & 1036899.50 & & \\
Fizyolojik Durumlar & Kiz & 1013 & 987.82 & 1000666.50 & 487075.5 & 0.066 \\
& Erkek & 1009 & 1035.27 & 1044586.50 & & \\
\hline
\end{tabular}

Cinsiyet değişkenine göre ortaokul öğrencilerinin matematik öz yeterlik düzeyleri arasında anlamlı bir farklılık olup olmadığını belirlemek amacıyla Mann-Whitney U testi yapılmıştır. Elde edilen bulgular, cinsiyet değişkenine göre kişisel deneyimler ( $p=0.161$, $\mathrm{p}>0.05)$, dolaylı yaşantılar $(\mathrm{p}=0.482, \mathrm{p}>0.05)$ ve sosyal iknalar $(\mathrm{p}=0.214, \mathrm{p}>0.05)$ ve fizyolojik durumlar $(\mathrm{p}=0.066, \mathrm{p}>0.05)$ alt boyutları ortalama puanları arasında $\mathrm{p}>.05$ olması sebebiyle anlamlı bir farklılık olmadığı belirlenmiştir.

Tablo 4. Sınıf düzeyi değişkenine göre ortaokul (5.-8. sınıf) öğrencilerinin matematik öz yeterlik kaynakları ölçeği alt boyutlarına ilişkin Kruskal Wallis test sonuçları

\begin{tabular}{|c|c|c|c|c|c|c|c|}
\hline $\begin{array}{l}\text { Ölçek Alt } \\
\text { Boyutları }\end{array}$ & $\begin{array}{l}\text { Sinıf } \\
\text { düzeyi }\end{array}$ & $\mathrm{n}$ & $\begin{array}{l}\text { Siralar } \\
\text { Ort. }\end{array}$ & $X^{2}$ & $\mathrm{df}$ & $\mathrm{p}$ & Anlamlı Farklılık \\
\hline \multirow{5}{*}{$\begin{array}{l}\text { Kişisel } \\
\text { Deneyimler }\end{array}$} & 5 & 550 & 1223.33 & 126.178 & 3 & 0.000 & $5-6,5-7,5-8,6-8,7-8$ \\
\hline & 6 & 401 & 1006.68 & & & & \\
\hline & 7 & 505 & 983.05 & & & & \\
\hline & 8 & 566 & 834.45 & & & & \\
\hline & Toplam & 2022 & & & & & \\
\hline \multirow{5}{*}{$\begin{array}{l}\text { Dolaylı } \\
\text { Yaşantılar }\end{array}$} & 5 & 550 & 1139.71 & 51.315 & 3 & 0.000 & $5-6,5-7,5-8,6-8,7-8$ \\
\hline & 6 & 401 & 1006.87 & & & & \\
\hline & 7 & 505 & 1011.89 & & & & \\
\hline & 8 & 566 & 889.84 & & & & \\
\hline & Toplam & 2022 & & & & & \\
\hline \multirow{5}{*}{ Sosyal İknalar } & 5 & 550 & 1223.54 & 133.611 & 3 & 0.000 & $5-6,5-7,5-8,6-8,7-8$ \\
\hline & 6 & 401 & 1027.95 & & & & \\
\hline & 7 & 505 & 978.37 & & & & \\
\hline & 8 & 566 & 823.36 & & & & \\
\hline & Toplam & 2022 & & & & & \\
\hline Fizyolojik & 5 & 550 & 916.60 & 50.316 & 3 & 0.000 & $5-8,6-8,7-8$ \\
\hline
\end{tabular}




\begin{tabular}{llll} 
Durumlar & 6 & 401 & 981.74 \\
& 7 & 505 & 980.98 \\
& 8 & 566 & 1152.04 \\
& Toplam & 2022 & \\
\hline
\end{tabular}

Sınıf düzeyi değişkenine göre öğrencilerin matematik öz yeterlik düzeyleri arasında anlamlı bir farklılık olup olmadığını belirlemek amacıyla Kruskal Wallis testi yapılmıştır. Elde edilen bulgular, sınıf düzeyine göre öğrencilerin kişisel deneyimler, dolaylı yaşantılar ve sosyal iknalar alt boyutu ortalama puanları arasında anlamlı bir farklılık olduğunu ortaya koymuştur. Bu farklılığın sınıf seviyesi yükseldikçe oluştuğu ve alt sınıf düzeylerinin lehine olduğu görülmektedir. Sınıf düzeyi değişkenine göre öğrencilerin kişisel deneyimler, dolaylı yaşantılar ve sosyal iknalara ilişkin görüşlerinin 5-6, 5-7, 5-8, 6-8, 7-8 sınıf düzeyleri arasında bir farklılık oluşturduğu belirlenmiştir. Sınıf seviyesine göre, matematik başarı notu değişkenine göre, öğrencilerin fizyolojik durumlar alt boyutu ortalama puanları arasında 5-8, 6-8, 7-8 sınıf düzeyleri arasında alt sınıfların lehine bir farklılık oluşturduğu görülmektedir.

Tablo 5. Matematik başarı notu değişkenine göre ortaokul (5-8. Sınıf) öğrencilerinin matematik öz yeterlik kaynakları ölçeği alt boyutlarına ilişkin Kruskal Wallis test sonuçları

\begin{tabular}{|c|c|c|c|c|c|c|c|}
\hline $\begin{array}{l}\text { Ölçek Alt } \\
\text { Boyutları }\end{array}$ & $\begin{array}{l}\text { Matematik } \\
\text { Başarı Notu }\end{array}$ & $\mathrm{n}$ & $\begin{array}{l}\text { Siralar } \\
\text { Ort. }\end{array}$ & $X^{2}$ & $\mathrm{df}$ & $\mathrm{p}$ & Anlamlı Farkl1lık \\
\hline \multirow{6}{*}{$\begin{array}{l}\text { Kişisel } \\
\text { Deneyimler }\end{array}$} & 1 & 66 & 419.83 & 664.939 & 4 & 0.000 & $\begin{array}{l}1-3,1-4,1-5,2-3,2-4,2- \\
5,3-4,3-5,4-5\end{array}$ \\
\hline & 2 & 204 & 576.57 & & & & \\
\hline & 3 & 460 & 699.99 & & & & \\
\hline & 4 & 445 & 917.75 & & & & \\
\hline & 5 & 847 & 1380.79 & & & & \\
\hline & Total & 2022 & & & & & \\
\hline \multirow{6}{*}{$\begin{array}{l}\text { Dolaylı } \\
\text { Yaşantılar }\end{array}$} & 1 & 66 & 632.39 & 233.889 & 4 & 0.000 & $\begin{array}{l}1-3,1-4,1-5,2-3,2-4,2- \\
5,3-4,3-5,4-5\end{array}$ \\
\hline & 2 & 204 & 726.82 & & & & \\
\hline & 3 & 460 & 849.26 & & & & \\
\hline & 4 & 445 & 953.65 & & & & \\
\hline & 5 & 847 & 1228.11 & & & & \\
\hline & Total & 2022 & & & & & \\
\hline \multirow{6}{*}{$\begin{array}{l}\text { Sosyal } \\
\text { İknalar }\end{array}$} & 1 & 66 & 492.15 & 575.576 & 4 & 0.000 & $\begin{array}{l}1-3,1-4,1-5,2-4,2-5,3- \\
4,3-5,4-5\end{array}$ \\
\hline & 2 & 204 & 613.93 & & & & \\
\hline & 3 & 460 & 696.86 & & & & \\
\hline & 4 & 445 & 947.67 & & & & \\
\hline & 5 & 847 & 1352.14 & & & & \\
\hline & Total & 2022 & & & & & \\
\hline $\begin{array}{l}\text { Fizyolojik } \\
\text { Durumlar }\end{array}$ & 1 & 66 & 1278.95 & 341.600 & 4 & 0.000 & $\begin{array}{l}1-5,2-4,2-5,3-4,3-5,4- \\
5,5-2,5-3,5-4\end{array}$ \\
\hline
\end{tabular}




\begin{tabular}{lll}
2 & 204 & 1278.97 \\
3 & 460 & 1267.93 \\
4 & 445 & 1099.59 \\
5 & 847 & 740.69 \\
Total & 2022 & \\
\hline
\end{tabular}

Tablo 5'te görüldüğü üzere, matematik başarı notu değişkenine göre, öğrencilerin kişisel deneyimler, dolaylı yaşantılar ve sosyal iknalar alt boyutu ortalama puanları arasında anlamlı bir farklılık olduğunu ortaya koymuştur. Bu farklılıkların 1-3, 1-4, 1-5, 2-4, 2-5, 3-4, 35, 4-5 sınıf düzeyleri arasında ve başarı notu yüksek olan öğrencilerin lehine olduğu görülmektedir. Buna ek olarak, matematik başarı notu değişkenine göre öğrencilerin fizyolojik durumlar alt boyutu ortalama puanları arasında başarı notu yüksek olan öğrencilerin lehine bir farklılık olduğu görülmektedir. Bu farklılığın 1-5, 2-4, 2-5, 3-4, 3-5, 4-5, 5-2, 5-3, 5-4 matematik başarı notları arasında olduğu görülmektedir.

Tablo 6. Anne eğitim durumu değişkenine göre ortaokul (5.-8. Sınıf) öğrencilerinin matematik öz yeterlik kaynakları ölçeği alt boyutlarına ilişkin Kruskal Wallis test sonuçları

\begin{tabular}{|c|c|c|c|c|c|c|c|}
\hline $\begin{array}{l}\text { Ölçek Alt } \\
\text { Boyutları }\end{array}$ & $\begin{array}{l}\text { Anne Eğitim } \\
\text { Durumu }\end{array}$ & $\mathrm{n}$ & $\begin{array}{l}\text { Siralar } \\
\text { Ort. }\end{array}$ & $X^{2}$ & $\mathrm{df}$ & $\mathrm{p}$ & Anlamlı Farklılık \\
\hline & İlkokul & 597 & 926.32 & 85.982 & 4 & 0.000 & $1-4,1-5,2-4,2-5,3-5$ \\
\hline & Ortaokul & 381 & 903.98 & & & & \\
\hline Kişisel & Lise & 604 & 1008.07 & & & & \\
\hline \multirow[t]{5}{*}{ Deneyimler } & M.Y.O. & 52 & 1141.10 & & & & \\
\hline & Üniversite & 388 & 1236.11 & & & & \\
\hline & Total & 2022 & & & & & \\
\hline & İlkokul & 597 & 951.01 & 25.549 & 4 & 0.000 & $1-4,1-5,2-4,2-5$, \\
\hline & Ortaokul & 381 & 956.31 & & & & \\
\hline Dolaylı & Lise & 604 & 1030.35 & & & & \\
\hline \multirow[t]{5}{*}{ Yaşantılar } & M.Y.O. & 52 & 1193.47 & & & & \\
\hline & Üniversite & 388 & 1105.05 & & & & \\
\hline & Total & 2022 & & & & & \\
\hline & İlkokul & 597 & 921.72 & 66.391 & 4 & 0.000 & $1-3,1-4,1-5,2-4,2-5$ \\
\hline & Ortaokul & 381 & 929.50 & & & & \\
\hline Sosyal & Lise & 604 & 1017.28 & & & & \\
\hline \multirow[t]{5}{*}{ İknalar } & M.Y.O. & 52 & 1148.23 & & & & \\
\hline & Üniversite & 388 & 1202.84 & & & & \\
\hline & Total & 2022 & & & & & \\
\hline & İlkokul & 597 & 1075.20 & 32.001 & 4 & 0.000 & $1-5,2-5,3-5$ \\
\hline & Ortaokul & 381 & 1083.64 & & & & \\
\hline Fizyolojik & Lise & 604 & 984.69 & & & & \\
\hline \multirow[t]{3}{*}{ Durumlar } & M.Y.O. & 52 & 983.64 & & & & \\
\hline & Üniversite & 388 & 888.13 & & & & \\
\hline & Total & 2022 & & & & & \\
\hline
\end{tabular}

1-ilkokul, 2-ortaokul, 3-lise, 4-MYO (Meslek Yüksekokulu), 5-üniversite 
Anne eğitim durumu değişkenine göre öğrencilerin kişisel deneyimler, dolaylı yaşantılar, sosyal iknalar ve fizyolojik durumlar alt boyutu ortalama puanları arasında anlamlı farklılıklar olduğu görülmektedir. Anne eğitim durumu yükseldikçe öğrencilerin kişisel deneyimler, dolaylı yaşantılar, sosyal iknalar ve fizyolojik durumlara yönelik öz yeterlik düzeylerinin olumlu yönde değiştiği söylenebilir.

Tablo 7. Baba eğitim durumu değişkenine göre ortaokul (5.-8. Sınıf) öğrencilerinin matematik öz yeterlik kaynakları ölçeği alt boyutlarına ilişkin Kruskal Wallis test sonuçları

\begin{tabular}{|c|c|c|c|c|c|c|c|}
\hline $\begin{array}{ll}\text { Ölçek Alt } \\
\text { Boyutları }\end{array}$ & $\begin{array}{l}\text { Baba Eğitim } \\
\text { Durumu }\end{array}$ & $\mathrm{n}$ & $\begin{array}{l}\text { Siralar } \\
\text { Ort. }\end{array}$ & $X^{2}$ & df & $\mathrm{p}$ & Anlamlı Farklılık \\
\hline \multirow[t]{6}{*}{$\begin{array}{l}\text { Kişisel } \\
\text { Deneyimler }\end{array}$} & İlkokul & 426 & 898.94 & 67.260 & 4 & 0.000 & $\begin{array}{l}1-4,1-5,2-4,2-5,3-4, \\
3-5\end{array}$ \\
\hline & Ortaokul & 439 & 951.13 & & & & \\
\hline & Lise & 594 & 980.72 & & & & \\
\hline & M.Y.O. & 73 & 1179.56 & & & & \\
\hline & Üniversite & 490 & 1175.72 & & & & \\
\hline & Total & 2022 & & & & & \\
\hline Dolaylı & İlkokul & 426 & 925.12 & 28.039 & 4 & 0.000 & $1-5,2-5,3-5$ \\
\hline \multirow[t]{5}{*}{ Yaşantılar } & Ortaokul & 439 & 981.93 & & & & \\
\hline & Lise & 594 & 998.87 & & & & \\
\hline & M.Y.O. & 73 & 1091.99 & & & & \\
\hline & Üniversite & 490 & 1116.40 & & & & \\
\hline & Total & 2022 & & & & & \\
\hline Sosyal & İlkokul & 426 & 897.52 & 62.078 & 4 & 0.000 & $1-4,1-5,2-4,2-5,3-5$ \\
\hline \multirow[t]{5}{*}{ İknalar } & Ortaokul & 439 & 947.77 & & & & \\
\hline & Lise & 594 & 993.09 & & & & \\
\hline & M.Y.O. & 73 & 1167.75 & & & & \\
\hline & Üniversite & 490 & 1166.72 & & & & \\
\hline & Total & 2022 & & & & & \\
\hline Fizyolojik & İlkokul & 426 & 1071.34 & 38.550 & 4 & 0.000 & $1-5,2-5,3-5$ \\
\hline \multirow[t]{5}{*}{ Durumlar } & Ortaokul & 439 & 1083.55 & & & & \\
\hline & Lise & 594 & 1022.33 & & & & \\
\hline & M.Y.O. & 73 & 1050.84 & & & & \\
\hline & Üniversite & 490 & 875.93 & & & & \\
\hline & Total & 2022 & & & & & \\
\hline
\end{tabular}

1-ilkokul, 2-ortaokul, 3-lise, 4-MYO (Meslek Yüksekokulu), 5-üniversite

Baba eğitim durumu değişkenine göre öğrencilerin kişisel deneyimler, dolaylı yaşantılar, sosyal iknalar ve fizyolojik durumlar alt boyutu ortalama puanları arasında anlamlı farklılıklar olduğu görülmektedir. Baba eğitim durumu yükseldikçe öğrencilerin kişisel deneyimler, dolaylı yaşantılar, sosyal iknalar ve fizyolojik durumlara yönelik öz yeterlik düzeylerinin olumlu yönde değiştiği söylenebilir. 
Tablo 8. Ölçek alt boyutları arasındaki korelasyon analizi sonuçları

\begin{tabular}{lcccc}
\hline & Kişisel Deneyimler & $\begin{array}{c}\text { Dolaylı } \\
\text { Yaşantılar }\end{array}$ & $\begin{array}{c}\text { Sosyal } \\
\text { Iknalar }\end{array}$ & $\begin{array}{c}\text { Fizyolojik } \\
\text { Durumlar }\end{array}$ \\
\hline Kişisel & - & $0.584^{* *}$ & $0.749^{* *}$ & $-0.402^{* *}$ \\
Deneyimler & $0.584^{* *}$ & - & $0.604^{* *}$ & $-0.314^{* *}$ \\
Dolaylı Yaşantılar & $0.749^{* *}$ & $0.604^{* *}$ & & $-0.397^{* *}$ \\
Sosyal İknalar & $-0.402^{* *}$ & $-0.314^{* *}$ & $-0.397^{* *}$ & \\
Fizyolojik & & & & \\
Durumlar & & & & \\
\hline
\end{tabular}

$\mathrm{N}=2022 ;{ }^{* *} \mathrm{p}<.01$,

Öğrencilerin öz yeterliklerine yönelik kişisel deneyimler, dolaylı yaşantılar, sosyal iknalar ve fizyolojik durumlara ilişkin görüşleri arasındaki ilişkinin derecesini ortaya koymak amacıyla Spearman sıra korelasyon analizi yapılmıştır. İki değişken arasındaki korelasyon katsayıları değerlendirilirken $.00-.25$ arası çok zayıf, .26-.49 zayıf, .50-.69 orta ve .70-.89 yüksek dereceli bir ilişki olarak tanımlanmaktadır (Sungur, 2009). Görüldüğü üzere kişisel deneyimler ve dolaylı yaşantılar ile dolaylı yaşantılar ve sosyal iknalar arasında orta dereceli pozitif bir ilişki olduğu görülmektedir. Kişisel deneyimler ve sosyal iknalar arasında yüksek dereceli pozitif bir ilişki olduğu görülmektedir. Kişisel deneyimler ve fizyolojik durumlar, dolaylı yaşantılar ve fizyolojik durumlar ile sosyal iknalar ve fizyolojik durumlar arasında zayıf dereceli negatif bir ilişki olduğu belirlenmiştir. İki değişken arasında pozitif bir ilişki olması aralarında doğrusal bir ilişkinin olduğunu göstermektedir. Bu iki değişken arasında negatif bir ilişki olması aralarında ters yönlü bir ilişkinin olduğunu göstermektedir

\section{Tartışma, Sonuç ve Öneriler}

$\mathrm{Bu}$ araştırma kapsamında ortaokul 5-8. sınıf öğrencilerinin matematik öz yeterlik kaynakları bazı değişkenler açısından ele alınarak incelenmiştir. Elde edilen sonuçlar, öğrencilerin matematik öz yeterlik düzeylerinin kişisel deneyimler, dolaylı yaşantılar ve sosyal iknalar kapsamında orta düzeyde olduğunu ortaya koymuştur. Fizyolojik durumlara ilişkin öğrencilerin matematik öz yeterliklerinin ise düşük olduğu belirlenmiştir. Bu çalışmaların tersine bazı araştırmalar (Adal \& Yavuz, 2017; Aldan Karademir \& Yalçın, 2019; Sevgi \& Zihar, 2020) öğrencilerin matematik öz yeterlik düzeylerinin yüksek olduğunu belirlemiştir.

Öğrencilerin matematik öz yeterlik düzeylerinin kaynakları olarak gösterilen kişisel deneyimler, dolaylı yaşantılar ve sosyal iknaların orta düzeyde oluşu bireylerin 
karşılaştıkları etkinlik, problem çözme ve ödev gibi çalışmalarda zaman zaman başarısızlık gösterdiklerine işaret ederken matematiksel becerilerinin az da olsa gelişim gösterdiği şeklinde yorumlanabilir. Benzer şekilde Bandura'nın (1997) belirttiği gibi başarısızlıkla sonuçlanan olumsuz deneyimlerin öz yeterliklerini olumsuz etkilediği söylenebilir. Öğrencilerin dolaylı yaşantılar yoluyla başkalarını (sınıf arkadaşlarını, aile üyelerini, televizyonun rolünü ve diğer medya araçlarını) gözlemleyerek inşa ettikleri (Bandura, 2004) öz yeterliklerinin orta düzeyde olduğu belirlenmiştir. Eccles ve diğerleri (1984) akran modellerin öğrencilerin dolaylı yaşantılar yoluyla geliştirdikleri öz yeterlikleri üzerinde önemli bir rolü olduğunu vurgulamaktadır. Bu çalışma rol modellerinin öğrencilerin öz yeterliklerinin gelişmesinde az da olsa olumlu bir rolünün olduğunu ortaya koymuştur. Bu sonuçlar öğrencilerin kendisine rol model olarak aldıkları akran, yetkin ve/veya çeşitli mesleklere sahip bireylerin spesifik olarak öğrenciler üzerindeki etkisine bakılması ihtiyacını ortaya koymuştur. Öğrencilerin güvendikleri kişilerin (ebeveynlerin, öğretmenlerin ve akranların) cesaretlendirmesinin matematik öz yeterlikleri üzerindeki rolü sosyal iknalar altında yer almaktadır (Senemoğlu, 2011). Bu çalışmada öğrencilerin sosyal iknalara yönelik öz yeterliklerinin orta düzeyde oluşu bu cesaretlendirir nitelikteki görüşmelerin çok yeterli olmadığını ortaya koymuştur. Bu durum öğrencilere verilen nasihat ve öğüt niteliğindeki ifadelerin ne derece öğrenciler üzerinde etkili olduğunun incelenmesi ihtiyacını ortaya koymuştur (Matsui vd., 1990). Fizyolojik durumlara ilişkin öğrencilerin matematik öz yeterliklerinin ise düşük olduğu belirlenmiştir. Kayg1, stres, bitkinlik gibi duygusal ve psikolojik durumlar içine alan fizyolojik durumlar öğrencilerin matematik dersi söz konusu olduğunda kaygı, stres, endişe gibi olumsuz duygu durumlarının baskın olduğunu ortaya koymuştur. Usher ve Pajares (2008b) bir derse yönelik bu tür olumsuz duygulara sahip bireylerin bu alana yönelik beceri eksiklerinin olduğunu vurgulamaktadır. Bu durum, kendisini matematik derslerinde yeterli görmeyen ve/veya eksikleri olduğunu düşünen öğrencilerin fiziksel ve duygusal olarak iyi oluşlarını geliştiremediklerini olumsuz duygusal durumların arttığına işaret etmektedir. Bu durum birçok çalışmadan elde edilen sonuçlarla paralellik göstermektedir (Britner \& Pajares, 2006; Gainor \& Lent, 1998; Lent vd., 1996).

Cinsiyet değişkenine göre ortaokul öğrencilerinin kişisel deneyimler, dolaylı yaşantılar, sosyal iknalar ve fizyolojik durumlarına ilişkin matematik öz yeterlik düzeyleri arasında anlamlı bir farklılık olmadığ görülmektedir. Buna paralel olarak, birçok araştırma (Akay \& Boz 2011; Britner \& Pajares, 2006; İsiksal \& Askar, 2005; Lent, Lopez vd., 1996; 
Pajares \& Graham, 1999; Pajares vd., 2007; Sevgi \& Yakışıklı 2020; Sevgi \& Zihar 2020) kız ve erkek öğrencilerin matematik öz yeterlik düzeylerinin benzer olduğunu ortaya koymuştur. Bununla beraber, bazı araştırmalar ise kız ve erkek öğrencilerin matematik öz yeterlik düzeyleri arasında anlamlı farklılıklar olduğunu belirlemiştir (Adal \& Yavuz, 2017; Aldan Karademir \& Yalçın, 2019; Louis \& Mistele, 2011; Medikoğlu, 2020; Pajares, 2005). Bu araştırmalardan bazıları erkek öğrencilerin matematik öz yeterlik düzeylerinin kızlardan daha yüksek olduğunu tespit etmiştir (Adal \& Yavuz, 2017; Aldan Karademir \& Yalçın, 2019; Louis \& Mistele, 2011; Pajares, 2005). Koç ve Arslan (2017) ile Medikoğlu (2020) ise kız öğrencilerin matematik öz yeterlik inançlarının erkek öğrencilerden daha yüksek olduğu sonucuna ulaşmıştır. Bu çalışmada $\mathrm{k} ı$ ve erkek öğrencilerin matematik öz yeterlik düzeylerinin benzer oluşu edinilen deneyimlerin birbirine yakın olduğuna işaret etmektedir.

Sınıf düzeyi değişkenine göre öğrencilerin kişisel deneyimler, dolaylı yaşantılar, sosyal iknalar ve fizyolojik durumlara yönelik görüşleri arasında anlamlı farklılıklar olduğu belirlenmiştir. Bu farklılıkların alt sınıflar lehine olduğu görülmektedir. Sınıf düzeyi yükseldikçe öğrencilerin öz yeterlik düzeylerinin azaldığı görülmektedir. Araştırmalar (Bandura 1997; Usher \& Pajares, 2008b) geçiş dönemlerinde (ilkokuldan ortaokula, ortaokuldan liseye) öğrencilerin matematik öz yeterlik düzeylerinin incelenmesi gerektiğini vurgulamaktadır. Bu çalışmadan elde edilen sonuçlar ilkokuldan ortaokula geçiş yapan 5. sınıf öğrencilerin lehine bir farklılaşma olduğunu ortaya koymuştur. Bu çalışmadan elde edilen sonuçlar bu farklılığın sınıf seviyesi yükseldikçe oluştuğunu ve alt sınıf düzeylerinin lehine olduğunu ortaya koymuştur. Bu çalışmadan elde edilen sonuçlara paralel olarak, Adal ve Yavuz (2017) ile Sevgi ve Zihar (2020) tarafından yapılan araştırmalar sınıf düzeyi değişkenine göre öğrencilerin matematik öz yeterlik düzeyleri arasında anlamlı farklılıklar olduğunu ve bu farklıkların alt sınıf düzeylerinin lehine olduğunu ortaya koymuştur. Bu sonuçlardan farklı olarak Çakıroğlu ve Işıksal (2009) çalışması ise sınıf düzeyi yükseldikçe öğrencilerin matematik öz yeterlik düzeyinin yükseldiğini tespit etmiştir. Öğrencilerin matematik başarı notu yükseldikçe, kişisel deneyimler, dolaylı yaşantılar, sosyal iknalar ve fizyolojik durumlara yönelik matematik öz yeterliklerinin olumlu yönde değiştiği belirlenmiştir. Öğrencilerin matematik başarı notu yükseldikçe öz yeterliklerinin olumlu yönde geliştiği söylenebilir. Bu sonucu destekler şekilde araştırmalar (Arens vd., 2020; Li vd., 2021) matematik öz yeterliğin matematik başarısı üzerinde önemli bir role sahip olduğunu belirlemiştir. Benzer şekilde, Butz ve Usher (2015) ilkokul ve ortaokul öğrencilerinin başarılı 
performanslarının öz yeterlikleri üzerinde önemli bir etkisi olduğunu ortaya koymuştur. Buna paralel olarak, Kahramanoğlu ve Deniz (2017) matematik öz yeterlik ile matematik başarısı arasında pozitif ve anlamlı bir ilişki olduğunu vurgulamaktadır. Sevgi ve Zihar (2020) tarafından yapılan çalışmalarda ise matematik karne notu değişkenine göre öğrencilerin matematik öz yeterlikleri arasında anlamlı bir farklılık olduğu ve bu farklılığın başarı notu yüksek olan öğrenciler lehine olduğu belirlenmiştir.

Anne ve baba eğitim durumu değişkenine göre öğrencilerin matematik öz yeterlik düzeyleri arasında anlamlı farklılıklar olduğu belirlenmiştir. Anne ve baba eğitim durumu yükseldikçe öğrencilerin kişisel deneyimler, dolaylı yaşantılar, sosyal iknalar ve fizyolojik durumlara yönelik öz yeterlik düzeylerinin olumlu yönde değiştiği söylenebilir. Bu durum anne ve baba eğitim durumunun öğrencilerin matematik öz yeterliklerinin gelişmesinde önemli bir yere sahip olduğunu ortaya koymaktadır. Bu çalışmaya paralel olarak Arslan (2017) ortaokul öğrencilerinin anne ve baba eğitim durumu değişkenine göre akademik öz yeterlik inançlarında anlamlı farklılıklar olduğu sonucuna ulaşmıştır. Bu farklılığın daha üst seviyedeki anne ve baba eğitim durumu lehine olduğu ortaya konmuştur. Medikoğlu (2020) çalışmasında ise ilkokul öğrencilerinin anne-baba eğitim durumu ve matematik ilgisi değişkenine göre matematik öz yeterlik düzeylerinde anlamlı farklılıklar tespit edilmiştir. Sosyal iknalar ve dolaylı yaşantılar ile anne-baba matematik ilgisi arasında anlamlı bir fark olduğu belirlenen bu araştırmada, kişisel deneyimler ve psikolojik durumlar alt faktörleri ile anne-baba matematik ilgisi arasında anlamlı bir farklılık olmadığı sonucuna ulaşılmıştır. Öğrencilerin öz yeterliklerine yönelik boyutları kişisel deneyimler ve dolaylı yaşantılar ile dolaylı yaşantılar ve sosyal iknalar arasında orta dereceli pozitif bir ilişki olduğu belirlenmiştir. Kişisel deneyimler ve sosyal iknalar arasında yüksek dereceli pozitif bir ilişki olduğu görülmektedir. Kişisel deneyimlerle fizyolojik durumlar, dolaylı yaşantılarla fizyolojik durumlar ve sosyal iknalarla fizyolojik durumlar arasında zayıf dereceli negatif bir ilişki olduğu belirlenmiştir.

$\mathrm{Bu}$ araştırmadan elde edilen sonuçlar ortaokul öğrencilerinin matematik öz yeterlik düzeylerini geliştirmek için edindikleri deneyimler, rol model olarak aldıkları bireyler, yetişkinler tarafından sunulan cesaretlendirici teşvik edici sözler ile duygusal durumlarını olumlu yönde gelişmesini sağlayacak deneyimlere olan ihtiyaçlarını ortaya koymuştur. Bu sebeple, bu çalışmanın devamı olarak karma desen bir çalışma yapılarak ortaokul öğrencilerinin ihtiyacı olan spesifik olumlu deneyimlerin belirlenmesi gerekmektedir. 
Matematik derslerinin gözlemlenmesi ile öğrencilerin matematik derslerine katılımları ve birbirleriyle ve öğretmenle olan etkileşimleri derinlemesine incelenebilir. Buna ek olarak, matematik derslerinde kullanılan ders notlarının, sınav sonuçlarının incelenmesi sağlanarak öğrencilerin süreç boyunca matematik derslerindeki başarıları ders içeriklerine bağlı olarak incelenebilir. Matematik derslerine yönelik yapılacak mülakatlar ile öğrencilerin öz yeterliklerinin gelişiminde önemli bir yeri olan kişisel deneyimler, dolaylı yaşantılar, sosyal iknalar ve fizyolojik durumlar hakkında daha fazla bilgi edinilebilir. Buna ek olarak, bu çalışma kapsamında veriler Kovid-19 ile başlayan pandemi sürecinden önce toplanmıştır. Özbey ve Koparan (2020) tarafından yapılan çalışma EBA destekli öğretimin öğrencilerin matematik başarılarını ve motivasyonlarını olumlu yönde etkilediğini ortaya koymuştur. Bu araştırmanın devamı olarak, karma desen bir çalışmayla pandemi sürecinde uzaktan öğretimle matematik derslerine katılan ortaokul öğrencilerinin öz yeterlik düzeyleri incelenebilir.

\section{Bilgilendirme}

Bu çalışmanın bir kısmı 16-19 Eylül 2020 tarihlerinde çevrim içi olarak düzenlenen Uluslararası Pegem Ĕ̆itim Kongresinde sözlü bildiri olarak sunulmuştur.

\section{Etik Kurul Belgesi}

Etik Kurul Komisyon Adı: Çanakkale Onsekiz Mart Üniversitesi Lisansüstü Ĕ̆itim Enstitüsü Etik Kurulu

Etik Kurul Belge Tarihi: 05/03/2020

Etik Kurul Belgesi Sayı ve Numara: 2020/18

Yazar Katkı Beyanı

Güney HACIÖMEROĞLU: Literatür Tarama, Araştırma Dizaynı, Veri Analizi, Uygulama, Ön Taslak Yazımı ve Düzenleme

Özlem ELMALI-ERDEM: Literatür Tarama, Veri Toplama, İnceleme-Yazma ve Düzenleme

\section{Kaynaklar}

Adal, A., \& Yavuz, İ. (2017). Ortaokul öğrencilerinin matematik öz yeterlik algıları ile matematik kaygı düzeyleri arasındaki ilişki. Uluslararası Alan Eğitimi Dergisi, 3(1), 2041. 
Akay, H., \& Boz, N. (2011). Sınıf öğretmeni adaylarının matematiğe yönelik tutumları, matematiğe karşı öz-yeterlik algıları ve öğretmen öz yeterlik inançları arasındaki ilişkilerin incelenmesi. Türk Ĕ̆itim Bilimleri Dergisi, 9(2), 281-312.

Aldan-Karademir, Ç., \& Yalçın, B. (2019). Ortaokul öğrencilerinin matematik öz yeterlik kaynaklarının incelenmesi. JASS Studies-The Journal of Academic Social Science Studies, 76, 383-396. doi: 10.29228/JASSS.29068.

Arens, A.K., Frenzel, A.C. \& Goetz, T. (2020). Self-concept and self-efficacy in math: longitudinal interrelations and reciprocal linkages with achievement. The Journal of Experimental Education, doi: 10.1080/00220973.2020.1786347.

Arslan, A. (2017). Ortaokul öğrencilerinin okuma kaygıları ve akademik öz yeterlik inançlarının çeşitli değişkenler açısından incelenmesi. E-Kafkas Eğitim Araştırmaları Dergisi, 4(3), 30-44. doi: 10.30900/kafkasegt.338051.

Arslan, A. (2018). Ortaokul öğrencilerinin konuşma kaygıları ve akademik öz-yeterlik inançlarının çeşitli değişkenler açısından incelenmesi. International e-Journal of Educational Studies (IEJES), 2(3), 26-43.

Arslan, A. (2019). Sağlık hizmetleri meslek yüksekokulu öğrencilerinin sosyal kaygıları ve genel öz-yeterlik algılarının çeşitli değişkenler açısından incelenmesi. International eJournal of Educational Studies (IEJES), 3(6), 78-96. doi: 10.31458/iejes.524860

Bandura, A. (1986). Social foundations of thought and action: A social cognitive theory. Englewood Cliffs, NJ: Prentice Hall.

Bandura, A. (1997). Self-efficacy the exercise of contml. New York: Freeman.

Bandura, A. (2004). Social cognitive theory for personal and social change by enabling media. In A. Singhal, M. J. Cody, E. M. Rogers, \& M. Sabido (Eds.), Entertainment education and social change: History, research, and practice (ss. 75-96). Mahwah, NJ: Lawrence Erlbaum.

Britner, S. L., \& Pajares, F. (2006). Sources of science self-efficacy beliefs of middle school students. Journal of Research in Science Teaching, 43, 485-499. doi:10.1002/tea.20131

Butz, A., R., \& Usher, E., L. (2015). Salient sources of early adolescents' self-efficacy in two domains. Contemporary Educational Psychology, 42, 49-61.

Chin, D., \& Kameoka, V. A. (2002). Psychosocial and contextual predictors of educational and occupational self-efficacy among Hispanic inner-city adolescents. Hispanic Journal of Behavioral Sciences, 24, 448-464. doi: 10.1177/0739986302238214

Cohen, L., Manion, L., \& Morrison, K. (2018). Research methods in education. London: Routledge.

Cooper, S. E., \& Robinson, D. A. G. (1991). The relationship of mathematics self- efficacy beliefs to mathematics anxiety and performance. Measurement and Evaluation in Counseling and Development, 24(1), 4-11.

Çakıroğlu, E., \& Işıksal, M. (2009). Preservice elementary teachers' attitudes and self efficacy beliefs toward mathematics. Education and Science, 34(151), 132-139.

Eccles, J. S., Midgley, C., \& Adler, T. (1984). Grade-related changes in the school environment: Effects on achievement motivation. In J. Nicholls (Ed.), Advances in 
motivation and achievement: The development of achievement motivation (Vol. 3, pp. 283331). Greenwich, CT: JAI Press.

Gainor, K. A., \& Lent, R. W. (1998). Social cognitive expectations and racial identity attitudes in predicting the math choice intentions of Black college students. Journal of Counseling Psychology, 45, 403-413. doi:10.1037/0022-0167.45.4.403

Gao, J. (2020). Sources of Mathematics Self-Efficacy in Chinese Students: a Mixed-Method Study with Q-Sorting Procedure. International Journal of Science and Mathematics Education, 18, 713-732. doi: 10.1007/s10763-019-09984-1

Gün, O., Acar-Şeşen, B., Akbulut, C., Çetin-Dindar, A., \& Molu, Z. (2021). Fen bilimleri ve ilköğretim matematik öğretmen adaylarının öz-yeterlik inançları ile öz yeterlik kaynaklarının incelenmesi. Yüzüncü Yıl Ĕ̆itim Fakültesi Dergisi, 18(1), 47-69.

Hackett, G., \& Betz, N. E. (1989). An exploration of the mathematics selfefficacy/mathematics performance correspondence. Journal for Research in Mathematics Education, 20(3), 261-273. doi: 10.2307/749515

Hampton, N. Z. (1998). Sources of academic self-efficacy scale: An assessment tool for rehabilitation counselors. Rehabilitation Counseling Bulletin, 41, 260-277.

Hampton, N. Z., \& Mason, E. (2003). Learning disabilities, gender, sources of selfefficacy, self-efficacy beliefs, and academic achievement in high school students. Journal of School Psychology, 41, 101-112.

İsiksal, M., \& Askar, P. (2005). The effect of spreadsheet and dynamic geometry software on the achievement and self-efficacy of 7th-grade students. Educational Research, 47(3), 333350. doi: 10.1080/00131880500287815

Johnson, R. D. (2005). An empirical investigation of sources of application-specific computerself-efficacy and mediators of the efficacy-performance relationship. International Journal of Human-Computer Studies, 62(6), 737-758. doi: 10.1016/j.ijhcs.2005.02.008

Kahramanoğlu, R., \& Deniz, T. (2017). Ortaokul öğrencilerinin üstbiliş becerileri, matematik öz yeterlikleri ve matematik başarısı arasındaki ilişkinin incelenmesi, İnönü Üniversitesi Eğitim Fakültesi Dergisi, 18(3), 189-200. doi: 10.17679/inuefd.334285

Kan, A. (2009). Ölçme sonuçları üzerinde istatistiksel işlemler. H. Atılgan (Ed.), Eğitimde ölçme ve değerlendirme (s.397-456), Ankara: Anı Yayıncılık.

Kandemir, M. A., \& Akbas-Perkmen, R. (2017). Examining validity of sources of mathematics self-efficacy scale in Turkey. European Journal of Educational Studies, 3(11), 69-88. doi:10.5281/zenodo.1041845

Karasar, N. (2003). Bilimsel araştırma yöntemi. Ankara: Nobel Yayıncilık.

Klassen, R. (2004). A cross-cultural investigation of the efficacy beliefs of South Asian immigrant and Anglo non-immigrant early adolescents. Journal of Educational Psychology, 96, 731-742. doi:10.1037/0022-0663.96.4.731.

Koç, C., \& Arslan, A. (2017). Ortaokul öğrencilerinin akademik öz yeterlik algıları ve okuma stratejileri bilişüstü farkındalıkları. Yüzüncü Yıl Üniversitesi Ĕğitim Fakültesi Dergisi, 14(1), 745-778. 
Lane, A. M. (2002). Relationships between performance toward accomplishment and selfefficacy in amateur boxing. Perceptual and Motor Skills, 94(3), 1056-1056. doi: 10.1177/003151250209400301.

Lent, R. W., Lopez, F. G., Brown, S. D., \& Gore, P. A. (1996). Latent structure of the sources of mathematics self-efficacy. Journal of Vocational Behavior, 49(3), 292-308. doi: 10.1006/jvbe.1996.0045

Li, H., Liu, J., Zhang, D., \& Liu, H. (2021). Examining the relationships between cognitive activation, self-efficacy, socioecnomic status, and achievement in mathematics: A multi-level analysis. British Journal of Educational Psychology. doi: 10.1111/bjep.12351

Lloyd, J. E.V., Walsh, J., \& Yailagh, M. S. (2005). Sex differences in performance attributions, self- efficacy, and achievement in mathematics: If I'm so smart, why don't I know it? Canadian Journal of Education, 28(3), 384-408.

Louis, R. A., \& Mistele, J. M. (2011). The differences in scores and self-efficacy by student gender in mathematics and science. International Journal of Science and Mathematics Education, Online First, 1-28.

Lopez, F. G., Lent, R. W., Brown, S. D., \& Gore, P. A. (1997). Role of socialcognitive expectations in high school students' mathematics-related interest and performance. Journal of Counseling Psychology, 44(1), 44-52. doi: 10.1037/0022-0167.44.1.44

Matsui, T., Matsui, K., \& Ohnishi, R. (1990). Mechanisms underlying math self-efficacy learning of college students. Journal of Vocational Behavior, 37, 223-238. doi:10.1016/00018791(90)90042-Z

Medikoğlu, O. (2020). İlkokul öğrencilerinin matematik öz yeterlik kaynakları ile matematik kayg1 düzeyleri arasındaki ilişkinin incelenmesi, Eğitim Kuram ve Uygulama Araştırmaları Dergisi, 6(1), 35-52. doi: 10.38089/ekuad.2020.2

Meece, J. L. (1991). The classroom context and students' motivational goals. In M. L. Maehr \& P. R. Pintrich (Eds.), Advances in motivation and achievement (Vol. 7, pp. 261-285). Greenwich, CT: JAI Press.

Özbey, A. \& Koparan, T. (2020). Eşitlik ve denklem konusunda eğitim bilişim ağı (EBA) destekli öğretimin ortaokul öğrencilerinin başarı, tutum ve motivasyonlarına etkisi. Journal of Computer and Education Research, 8(16), 453-475. doi: 10.18009/jcer.718801

Öztürk, M., Akkan, Y., \& Kaplan, A. (2020). Reading comprehension, mathematics selfefficacy perception, and mathematics attitude as correlates of students' non-routine mathematics problem-solving skills in Turkey. International Journal of Mathematical Education in Science and Technology, 51(7), 1042-1058.

Pajares, F. (2005). Gender differences in mathematics self-efficacy beliefs. In A. Gallagher \& J. Kaufman (Eds.), Mind gap: Gender differences in mathematics (ss. 294-315). Boston: Cambridge University Press.

Pajares, F., \& Graham, L. (1999). Self-efficacy, motivation constructs, and mathematics performance of entering middle school students. Contemporary Educational Psychology, 24(2), 124-139. doi: 10.1006/ceps.1998.0991 
Pajares, F., Johnson, M. J., \& Usher, E. L. (2007). Sources of writing self-efficacy beliefs of elementary, middle, and high school students. Research in the Teaching of English, 42, 104-120.

Pul, H.H., \& Aksu, H.H. (2020). Sınıf öğretmenleri ile sınıf öğretmeni adaylarının matematik öğretimine yönelik öz yeterlilik inançları. Eğitim Kuram ve Uygulama Araştırmaları Dergisi, 6(1), 99-114.

Senemoğlu, N. (2011). College of education students' approaches to learning and study skills. Educational Sciences. 36(160), 65-80.

Sevgi, S., \& Yakışıklı, Z. (2020). Ortaokul öğrencilerinin matematik öz-yeterlik algılarının ve matematiğe yönelik tutumlarının incelenmesi. Mersin Üniversitesi Ĕ̆itim Fakültesi Dergisi, 16(2): 394-416. doi: 10.17860/mersinefd.685426

Sevgi, S., \& Zihar, M. (2020). Ortaokul öğrencilerinin yansıtıcı düşünme becerileri ile matematik öz yeterlik algılarının çeşitli değişkenler açısından incelenmesi. Kastamonu Education Journal, 28(6), 2331-2345. doi: 10.24106/kefdergi.700428

Schunk, D. H. (1984). Sequential attributional feedback and children's achievement behaviors. Journal of Educational Psychology, 76(6), 1159-1169. doi: 10.1037/00220663.76.6.1159

Sungur, O. (2009). Korelasyon analizi. Ş. Kalaycı (Ed.), SPSS uygulamalı çok değgişkenli istatistik teknikleri. 116-125. Ankara: Asil Yayıncılık.

Ulukaya, F., Yıldırım, N., \& Ozzeke, V. (2017). Okul yöneticilerinin teknoloji liderliği özyeterlikleri ile eğitim öğretim işlerini gerçekleştirme düzeylerine ilişkin algıları. Journal of Computer and Education Research, 5(10), 125-149. doi: 10.18009/jcer.292439

Usher, E. L., \& Pajares, F. (2008a). Self-efficacy for self-regulated learning: A validation study. Educational and Psychological Measurement, 68, 443-463. doi:10.1177/0013164407308475

Usher, E. L., \& Pajares, F. (2008b). Sources of self-efficacy in school: Critical review of the literature and future directions. Review of Educational Research, 78, 751-796. doi:10.3102/0034654308321456

Usher, E. L. \& Pajares, F. (2009). Sources of self-efficacy in mathematics: A validation study. Contemporary Educational Psychology, 34, 89-101. 